\title{
Influence of Sustainable Fertilization on Yield and Quality Food of Mountain Grassland
}

\author{
Costel SAMUIL*, Mihai STAVARACHE, Culiță SÎRBU, Vasile VÎNTU \\ University of Agricultural Sciences and Veterinary Medicine, Department of Plant Science, Faculty of Agriculture, 3 Sadoveanu Alley, 700490, \\ Iasi,România; csamuil@uaiasi.ro (*correspondingauthor);mihaistavarache@uaiasi.ro; csirbu@univagro-iasi.ro; vvintu@uaiasi.ro
}

\begin{abstract}
The semi-natural grasslands in Romanian mountains are particularly important for the sustainable development of this region. Therefore, the objective of this paper was to evaluate the effects of mineral and manure fertilization upon the sward in order to recommend certain versions which have minor repercussions upon the plant diversity. In this study, we examined the influence of organic and mineral fertilizers on the production, biodiversity and quality of green fodder. The experiment was set up in mountain grassland of Festuca rubra L. and Agrostis capillaris L., during five years. In the experiment was evaluated the effects of management treatments on productivity, biodiversity and quality of the forage grass. The rate applications of fertilizers determine the number of species and the rate of production. The small quantities of organic and mineral nutrients (10 t.ha ${ }^{-1}$ manure and $30 \mathrm{~kg} \cdot \mathrm{ha}^{-1}$ nitrogen) can lead to larger yields while at the same time, improving biodiversity conservation and the quality of forage. Using a low input-based management system can be a solution that will lead to higher yields and contribute to biodiversity conservation and the good quality of the forage. In conclusion the use of a fertilizer management regime based on small quantities of organic and mineral nutrients can lead to larger yields while at the same time, improving biodiversity conservation and the quality of forage.
\end{abstract}

Keywords: biodiversity; chemical composition; plant nutrition; quality feed; species richness

\section{Introduction}

Permanent pastures, in Romania represent $33 \%$ of the total agricultural area ( 4.9 million ha) and are an important forage resource but inappropriate management systems in the past have led to their present state of degradation (Vîntu et al., 2011a; Samuil et al., 2012a). Only, the Festuca rubra L. and Agrostis capillaris L. grasslands occupy an area of approximately 1.6 million ha and are characterised by relatively low grass production rates.

Many management factors may affect the biodiversity of semi-natural grasslands, including fertilization, grazing and cutting regime (Chytrý et al., 2009; Duru et al., 2010; Hejcman et al., 2010; Pasho et al., 2011).

Increasing the productive potential of these grasslands can be achieved through fertilization with different rates and types of manure fertilizers (Hopkins et al., 1990; Chapin et al., 2000; Kesting et al., 2009). The species and community diversity of grasslands is a result of a traditional extensive grassland management system interacting with a broad range of site conditions (Louault et al., 2004; Assaf et al., 2011; Sîrbu et al., 2012).
The naturally highly productive grasslands are much less threatened by the inappropriate application of fertilizers than low productive grasslands with a specific plant species composition (Honsová et al., 2007).

If applied regularly and judiciously, organic fertilizers can be used as a substitute for chemical fertilizers (Vîntu $e t$ al., 2011b). Comparative studies, which investigated the effects of different management practices on grasslands, have demonstrated that changes do occur in species diversity depending on management practices (Hopkins et al., 1999). Floristic composition influences the nutritional value of semi-natural grasslands due to differences in the chemical composition, digestibility of individual species and variation in the growth rate of different species (Andueza $e t$ al., 2010; Oates et al., 2011; Dale et al., 2012; Samuil et al., 2012b).

Some studies investigated the long-term effects on sward composition and forage quality of applying different fertilizer regimes to upland permanent pasture ( $\mathrm{Yu}$ et al., 2011). In species-rich grasslands, the digestibility of forage grasses is usually lower than the digestibility of forage grasses produced by grasslands used for intensive production (Bruinenberg et al., 2002). Feed test results can be used to improve future crop management if the forage is of 
unsatisfactory quality. For the forage user, feed analysis provides many of the inputs needed to formulate rations so that the forage is used effectively (Coleman and Moore, 2001).

The previous experiments organized in Romania presented separate the influences of different inputs on the production, plant composition species or quality of the forage. The aim of this study was to answer the following questions: (i) how does Festuca rubra L. and Agrostis capillaris L. grassland respond to different fertilization treatments in terms of forage dry matter (DM) production; (ii) are there any changes in plant species composition, in plant biodiversity and in functional plant groups under the different fertilization treatments, and if so, what are the temporal trends over six consecutive years and (iii) how does forage quality respond to different fertilization treatments?

\section{Materials and Methods}

\section{Site description}

In 2009, the fertilizer experiment was set up on the Campulung Moldovenesc, Suceava County (Romania, 47 $52^{\prime}$ $\mathrm{N}, 25^{\circ} 47^{\prime} \mathrm{E}$, at $727 \mathrm{~m}$ a.s.l. and a $16^{\circ}$ slope, with west exposition) on a Festuco rubrae - Agrostietum capillaris Horvat 1951 subass. nardetosum strictae.

The type soil was Typic Dystrudepts, according to the American System or Dystric Cambisol according World Reference Base for Soil Resources (WRB-SR). The soil had a pH (measured in $\mathrm{H}_{2} \mathrm{O}$ ) of 4.7 and average nutrient contents were: total $\mathrm{N}$ content, $1.3 \mathrm{~g} \mathrm{~kg}^{-1}$; P content, $0.33 \mathrm{~g} \mathrm{~kg}^{-1}$ and $\mathrm{K}$ content, $14.6 \mathrm{~g} \mathrm{~kg}^{-1}$.

\section{Experimental treatments}

The experiment was arranged in completely randomised blocks, with four replications and a plot size of $4 \mathrm{~m} \times 5 \mathrm{~m}$ harvested. There are seven different treatments, and fertilizer application rates are shown in Table 1.

The chemical composition of $1000 \mathrm{~kg}$ of manure was $5.19 \mathrm{~kg}$ $\mathrm{N}, 2.83 \mathrm{~kg} \mathrm{P}_{2} \mathrm{O}_{5}$ and $6.72 \mathrm{~kg} \mathrm{~K} \mathrm{~K}_{2} \mathrm{O}$. The manure was applied during the autumn season whereas the mineral nitrogen was applied in every spring before vegetation growth began.

Harvesting was performed by mowing throughout the earring phase of the dominant grass, and the final yield was expressed as dry matter (t.ha $\left.{ }^{-1} \mathrm{DM}\right)$. In the years 2009 and 2010, when growth was poor, there was only one harvest (July). However, in all other years there were two harvests (June and September). The cutting was performed with Bertollini 411 harvester, at a height of $4-5 \mathrm{~cm}$ above ground.

\section{Climatic conditions}

The climatic conditions were characterized by average temperatures of $6.3^{\circ} \mathrm{C}$ and total annual precipitation of 708.2 $\mathrm{mm}$. For the last 50 years, the period between April to September was characterized by an average temperature of $12.8^{\circ} \mathrm{C}$ and an average rainfall of $513.5 \mathrm{~mm}$. In terms of climate, the area is situated in the north eastern part of the Central European Province, benefiting from a continental moderatetemperate climate with influences from the eastern continental climate as well as the northern boreal.

\section{Methods and chemical analyses}

For compare the effect of different types and combinations of organic and mineral nitrogen fertilizers, was used the Used Apparent Coefficient (UAC). The UAC gives an indication of the effective use of organic nitrogen on a short term basis (Lemaire et al., 1989).

The UAC varies depending on the time of application and type of vegetation cover. The UAC of the nitrogen equivalent on mineral fertilizer is the rate of nitrogen used really by plant. The UAC value is between 0 to $70 \%$. The results obtained in this experiment were based on a UAC value of 0.4 for manure applied annually, 0.45 for manure applied every two years and 0.55 for manure applied every three years (Lemaire et al., 1989).

All species within the study area were categorized according to their main traits. The following basic functional groups were recognized: grasses, legumes and herbs. Grasses and other herbs (not legumes) were further categorized into short graminoids, short herbs, tall graminoids and tall herbs. To obtain total cover of functional groups, the covers of individual species belonging to a particular group were summed.

Plant species composition analysis was performed using the number of species, the Shannon Weaver index, the Simpson index and the equity index. We recorded the presence/absence data and also plant cover. The cover of all vascular plant species was estimated in each plot based on the Braun-Blanquet methodology (Cristea et al., 2004). To eliminate edge effects, relevés were taken in the center of each $4 \mathrm{~m} \times 5 \mathrm{~m}$ plot in an area of $2 \mathrm{~m} \times 3 \mathrm{~m}$ in mid-June 2014. The total number of vascular plant species was counted directly in the field.

Quality analyses, performed in a specialized laboratory, took into consideration the fodder from the first cut of the 2014 . Samples were analysed for content of Dry Matter (DM), acid detergent fibre $(\mathrm{ADF})$, neutral detergent fibre (NDF) and acid detergent lignin. Dry matter was determined after drying at $60^{\circ} \mathrm{C}$ and ash after combustion at $550^{\circ} \mathrm{C}$. Fat content was determined as described in ISO 6492, using Soxhlet apparatus.

Digestible Dry Matter (DDM), Digestible Dry Matter Intake (DMI), Total Digestible Nutrients (TDN), Net Energy-

Table 1. Fertilization methods used and the amounts of nutrients supplied to the treatments

\begin{tabular}{|c|c|c|c|}
\hline Treatments & Nitrogen $\left(\mathrm{kg} \cdot \mathrm{ha}^{-1}\right)$ & Manure $\left(\mathrm{t} \cdot h \mathrm{~h}^{-1}\right)$ & Total nitrogen application rates with $\mathrm{UAC}=0.4 ; 0.45 ; 0.55$ \\
\hline $\mathrm{a}_{0} \mathrm{~b}_{0} \mathrm{C}_{0}$ & 0 & 0 & 0 \\
\hline albicl & 30 & 10 & 50 \\
\hline $\mathrm{a}_{1} \mathrm{~b}_{1} \mathrm{c}_{2}$ & 50 & 10 & 70 \\
\hline $\mathrm{a}_{2} \mathrm{~b}_{2} \mathrm{c}_{1}$ & 30 & 20 & 53 \\
\hline $\mathrm{a}_{2} \mathrm{~b}_{2} \mathrm{c}_{2}$ & 50 & 20 & 73 \\
\hline $\mathrm{a}_{3} \mathrm{~b}_{3} \mathrm{C}_{1}$ & 30 & 30 & 59 \\
\hline $\mathrm{a}_{3} \mathrm{~b}_{3} \mathrm{c}_{2}$ & 50 & 30 & 79 \\
\hline
\end{tabular}

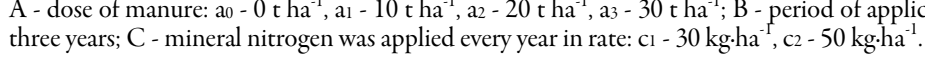


412

Lactation, Relative Feed Value (RFV) and Relative Feed Quality (RFQ) were calculated. RFV value is an index that combines the important nutritional factors of intake and digestibility and it does not have units. The relationships used for calculating these fodder quality parameters are the direct results of experiments and interpretations made by specialists in animal.

Acid detergent fiber $(\mathrm{ADF})$ value refers to the cell wall portions of the forage that are made up of cellulose and lignin. These values are important because they relate to the ability of an animal to digest forage. As $\mathrm{ADF}$ increases, digestibility of the forage usually decreases. Forage with ADF levels above $45 \%$ have little nutritive value and forage with $\mathrm{ADF}$ levels lower than 31\% are excellent. Neutral detergent fiber (NDF) is a useful indicator of forage intake potential, which declines with increasing NDF values. Forage with NDF values below $40 \%$ are excellent and forage with a NDF of $65 \%$ or greater are unlikely to be eaten by most animals. TDN is highly correlated with energy content in feeds. Relative feed value (RFV) is an index that combines the important nutritional factors of intake and digestibility. RFV is an index to rank the forage based on a calculation of DDM and DMI. The forage with an ADF of $41 \%$ and NDF of $53 \%$ is considered an index of 100 . When the forage RFV is above 100, it is not necessarily for superior forage. Relative feed value is an index that combines intake and digestibility values. A high RFV reflects higher quality, greater intake and higher digestibility. The RFQ index reflects differences in growing conditions due to ambient temperatures, which impact dNDF. However, the Relative Feed Quality index has superseded the RFV index as the forage quality index.

Total nitrogen was determined using the Kjeldahl method (ISO 1332). The ADF and NDF were determined using the Van Soest method (Sara et al., 2005).

The nitrogen nutrition index (NNI) was determined using the following formula:

$$
\mathrm{NNI}=100 \times \mathrm{N} / 4.8 \times(\mathrm{DM})^{-0.32}(\text { Lemaire } \text { et al., 1989), }
$$

where: $\mathrm{N}$ - nitrogen content of the plant (\%) and DM - dry matter production $\left(\mathrm{t} \cdot \mathrm{ha}^{-1}\right)$.

The nitrogen nutrition status was considered normal when the NNI varied between 80 and $100 \%$. Lower values showed that nitrogen levels were insufficient and higher values indicated a nutritional excess.

\section{Statistical analyses}

Data regarding the share of economic groups, species number and Shannon Index (SI) were processed by analysis of variance. For the production yields, statistical analyses were performed using ANOVA, applying the Least Significant Difference (LSD) test.

\section{Results}

\section{Biomass yield and plant nutrition}

Yields were influenced by the application rates and combinations of fertilizers applied. As, expected, the data on biomass yield indicated considerable annual variation (Table 2).

During the study period 2009-2014, the total biomass production responded to nitrogen and manure application. Biomass production increased significant with the addition of $\mathrm{N}$ or manure in all treatments. The highest yields recorded by the control variant were obtained in 2010 and 2011 (3.9 t.ha $\mathrm{a}^{-1}$ and $4.0 \mathrm{t} \cdot \mathrm{ha}^{-1}$, respectively). When production data over the 6 years was analysed, the results showed that the largest yields occurred in 2011 followed by 2009 whereas the lowest yields occurred in 2009 followed by 2014 . Average yields varied between $3.3 \mathrm{t} \cdot \mathrm{ha}^{-1}$, for the control treatment and 5.0 t.ha ${ }^{-1}$ for the $a_{1} b_{1} c_{2}$ treatment. Based on statistical analyses, biomass production was positively affected by $\mathrm{N}$ and manure in all variants of fertilization and in all years (LSD 0.05).

The effect of various combinations and application rates of organic and mineral fertilizers was assessed using the UAC coefficient. According to this assessment, the greatest increase in production occurred with the $a_{1} b_{1} c_{1}$ treatment where a nitrogen rate of $98 \mathrm{~kg}^{-1}$ was applied. This was followed by the $\mathrm{a}_{2} \mathrm{~b}_{2} \mathrm{c}_{1}$ treatment where $85 \mathrm{~kg} \cdot \mathrm{kg}^{-1}$ nitrogen was applied (Table 3).

The smallest increase, in terms of final output, occurred with the $a_{3} b_{3} c_{2}$ treatment where only $62 \mathrm{~kg} \cdot \mathrm{kg}^{-1}$ of nitrogen was applied. The $a_{2} b_{2} c_{1}$ and $a_{1} b_{1} c_{1}$ fertilization treatments were the most effective in terms of increase in percentage output. The value of nitrogen exported by means of production reached $40 \mathrm{~kg} \cdot \mathrm{ha}^{-1}$ in the $\mathrm{a}_{0} \mathrm{~b}_{0} \mathrm{c}_{0}$ treatment, whereas in the other fertilization treatments it ranged between 47 and $69 \mathrm{~kg} \cdot \mathrm{ha}^{-1}$. The largest amount of nitrogen exported by means of production was recorded by the $\mathrm{a}_{3} \mathrm{~b}_{3} \mathrm{c}_{2}$ treatment. This was due to both the high fodder yields produced by this treatment ( $4.3 \mathrm{t}^{-\mathrm{ha}^{-1}}{ }^{-1}$ and to the high percentage of total nitrogen in the fodder $\left(16.1 \mathrm{~g} \cdot \mathrm{kg}^{-1} \mathrm{DM}\right)$. The lowest coefficient of nitrogen use, 13-165, was recorded by the $a_{2} b_{2} c_{1}$ and $a_{2} b_{2} c_{2}$ treatments where manure had been applied every 2 years. The highest UAC coefficient of 37$42 \%$ was recorded by the $a_{3} b_{3} c_{1}$ and $a_{3} b_{3} c_{2}$ treatments where manure had been applied every 3 years. There was a positive

Table 2. Evolution of DM production during the experiment $\left(\mathrm{t} \cdot \mathrm{h} \mathrm{a}^{-1}\right)$

\begin{tabular}{|c|c|c|c|c|c|c|c|c|}
\hline Treatments & 2009 & 2010 & 2011 & 2012 & 2013 & 2014 & $2009-2014$ & SE \\
\hline $\mathrm{a}_{0} \mathrm{~b}_{0} \mathrm{c}_{0}$ & 2.7 & 3.9 & 4.0 & 3.1 & 3.2 & 2.9 & 3.3 & 0.21 \\
\hline albicl & $3.8^{*}$ & $54^{*}$ & $6.4^{*}$ & $4.8^{*}$ & $4.8^{*}$ & $4.0^{*}$ & $4.9^{*}$ & 0.30 \\
\hline$a_{1} b_{1} c_{2}$ & $4.2^{*}$ & $5.6^{*}$ & $6.8^{*}$ & $4.6^{*}$ & $4.7^{*}$ & $3.9^{*}$ & $5.0^{*}$ & 0.27 \\
\hline $\mathrm{a}_{2} \mathrm{~b}_{2} \mathrm{c}_{1}$ & $4.3^{*}$ & $5.4^{*}$ & $6.0^{*}$ & $4.4^{*}$ & 3.9 & 3.2 & $4.5^{*}$ & 0.18 \\
\hline$a_{2} b_{2} c_{2}$ & $4.5^{*}$ & $5.8^{*}$ & $6.1^{*}$ & $4.5^{*}$ & $4.4^{*}$ & $3.5^{*}$ & $4.8^{*}$ & 0.15 \\
\hline $\mathrm{a}_{3} \mathrm{~b}_{3} \mathrm{c}_{1}$ & $4.5^{*}$ & $5.7^{*}$ & $5.8^{*}$ & $3.9^{*}$ & $4.3^{*}$ & $4.1^{*}$ & $4.7^{*}$ & 0.24 \\
\hline$a_{3} b_{3} c_{2}$ & $4.6^{*}$ & $5.8^{*}$ & $5.8^{*}$ & $4.0^{*}$ & $4.9^{*}$ & $4.3^{*}$ & $4.9^{*}$ & 0.15 \\
\hline SE & 0.14 & 0.25 & 0.30 & 0.25 & 0.26 & 0.33 & 0.09 & \\
\hline LSD 0.05 & 0.3 & 0.5 & 0.9 & 0.7 & 0.8 & 0.6 & 0.3 & \\
\hline
\end{tabular}

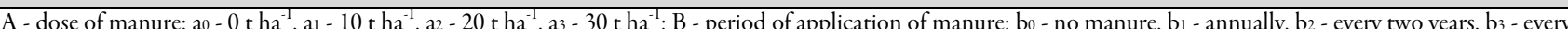
three years; C - mineral nitrogen was applied every year in rate: $\mathrm{c}_{1}-30 \mathrm{~kg} \cdot \mathrm{ha}{ }^{-1}, \mathrm{c}_{2}-50 \mathrm{~kg} \cdot \mathrm{ha}^{-1}$; The mean difference is significant at 0.05 level 
Table 3. Total nitrogen application rates with UAC and dry matter production $/ \mathrm{kg}$ nitrogen

\begin{tabular}{|c|c|c|c|c|c|}
\hline Treatments & $\begin{array}{c}\text { Total nitrogen application } \\
\text { rates with UAC }\end{array}$ & $\begin{array}{c}\mathrm{kg} \cdot \mathrm{kg}^{-1} \mathrm{DM} \text { nitrogen } \\
\text { applied }\end{array}$ & $\begin{array}{c}\text { kg.ha }{ }^{-1} \text { total } \mathrm{N} \\
\text { exported }\end{array}$ & $\begin{array}{c}\text { Use of applied } \\
\text { nitrogen ratio }(\%)\end{array}$ & NNI \\
\hline $\mathrm{a}_{0} \mathrm{~b}_{0} \mathrm{c}_{0}$ & 0 & - & 40 & - & 40 \\
\hline aıbicl & 50 & 98 & 58 & 36 & $47^{*}$ \\
\hline $\mathrm{a}_{1} \mathrm{~b}_{1} \mathrm{c}_{2}$ & 70 & 71 & 55 & 21 & $45 \mathrm{~ns}$ \\
\hline $\mathrm{a}_{2} \mathrm{~b}_{2} \mathrm{Cl}_{1}$ & 53 & 85 & 47 & 13 & $44 n s$ \\
\hline $\mathrm{a}_{2} \mathrm{~b}_{2} \mathrm{c}_{2}$ & 73 & 65 & 52 & 16 & $46^{*}$ \\
\hline $\mathrm{a}_{3} \mathrm{~b}_{3} \mathrm{c}_{1}$ & 59 & 80 & 65 & 42 & $52^{*}$ \\
\hline $\mathrm{a}_{3} \mathrm{~b}_{3} \mathrm{c}_{2}$ & 79 & 62 & 69 & 37 & $53^{*}$ \\
\hline LSD 0.05 & & & & & 6 \\
\hline
\end{tabular}

correlation between the amount of equivalent applied nitrogen and the amount of nitrogen exported. If nitrogen nutritional status is considered normal when values vary between 80 and 100, it can be seen that all the fertilized treatments show NNI values under $80 \%$. This indicates that the soil nutritional status was too low. The application rates of nitrogen need to be higher. Furthermore, a higher rate would not lead to the release of excess nitrogen that could have negative effects on the fodder crop and biodiversity.

\section{Plant species composition}

In 2014, a total of 36 species were identified of which 12 belonged to the Poaceae family, 8 belonged to the Fabaceae family and 16 species belonged to other botanical families (Table 4).

Consistency is an expression of the presence of a species related to the surfaces allocated for each species taken from the association and it provides information on the degree of fidelity. Over $60 \%$ of the species included statistically significant in the study recorded a constant and very good quality, falling into classes IV and V. Analysing the biodiversity parameters highlighted the fact that the number of species increased in all the fertilized treatments compared to treatment $\mathrm{a}_{0} \mathrm{~b}_{0} \mathrm{c}_{0}$ (Table 5).

At the same time, the Shannon index increased statistically significant from 2.202 in the $\mathrm{A}_{0} \mathrm{~b}_{0} \mathrm{c}_{0}$ treatment to 2.805-2.964 in the fertilized treatments. Shannon evenness varied between 0.745 and 0.895 for treatments $a_{0} b_{0} c_{0}, a_{3} b_{3} c_{2}$ and $a_{1} b_{1} c_{2}$. The Simpson index was 0.225 for $a_{0} b_{0} c_{0}$ and ranged between $0.070-0.089$ for the fertilized treatments. Species richness was significantly affected by treatment. The following species were associated with the control: Achillea millefolium, Agrostis capillaris, Briza media, Filipendula vulgaris, Nardus stricta, Plantago lanceolata and Potentilla erecta. In contrast, Arrhenatherum elatius, Dactylis glomerata, Festuca rubra, Lotus corniculatus, Trifolium pretense and Trifolium repens were associated with the $\mathrm{N}$ and manure treatment.

In our experiment, the relatively little effect of treatment on the presence of dominant grasses contrasts with the results of other long-term experiments on low productive grasslands, where the dominant species in the control disappeared after several decades of nutrient application. The initially dominant species persisted in all treatments, differing only in percentage cover species richness was positively correlated with the amount of $\mathrm{N}$ and manure applied (Păcurar et al., 2012).
Arrhenatherum elatius, Festuca rubra and Dactylis glomerata were the dominant grasses under the fertilizer application. Lotus corniculatus, Trifolium pretense and Trifolium repens were the dominant legumes under the fertilizer application. The observation that dominant grass species from control such Nardus stricta and Briza media were replaced by Arrhenatherum elatius, Festuca rubra, Lotus corniculatus, Trifolium pretense and Trifolium repens is not new. Arrhenatherum elatius and Festuca rubra were usually described as a nitrophilous species wich were also capable of growing under low soil fertility.

The increase in species richness was similar in all treatments, indicating that the effect of fertilizers types on species richness was almost independent of rates.

\section{Chemical composition and quality of the forage}

Chemical analysis of the fodder showed that total nitrogen was influenced by the fertilizer application rate, which ranged from $13.7 \mathrm{~g} \cdot \mathrm{kg}^{-1}$ for the $\mathrm{a}_{0} \mathrm{~b}_{0} \mathrm{c}_{0}$ treatment to $16.1 \mathrm{~g} \cdot \mathrm{kg}^{-1}$ for the $\mathrm{a}_{3} \mathrm{~b}_{3} \mathrm{c}_{2}$ treatment (Table 6).

The ADF content of $a_{0} b_{0} c_{0}$ was $427.6 \mathrm{~g}^{-1} g^{-1}$ and it ranged between $404.7 \mathrm{~g}^{\mathrm{kg}}{ }^{-1}$ for $\mathrm{a}_{2} \mathrm{~b}_{2} \mathrm{c}_{1}$ and $452.5 \mathrm{~g} \mathrm{~kg}^{-1}$ for $a_{3} b_{3} c_{2}$. The lower ADF values of the $a_{2} b_{2} c_{2}$ and $a_{2} b_{2} c_{1}$ variants showed that these treatments produced grass with a superior fodder digestibility. The NDF content was 521.3 $\mathrm{g} \cdot \mathrm{kg}^{-1}$ for the $\mathrm{a}_{0} \mathrm{~b}_{0} \mathrm{c}_{0}$ treatment whereas values of $469.3 \mathrm{~g} \cdot \mathrm{kg}^{-1}$ and $504.7 \mathrm{~g} \cdot \mathrm{kg}^{-1}$ were recorded for $a_{1} b_{1} c_{1}$ and $a_{2} b_{2} c_{2}$, respectively.

DDM is calculated from ADF values and can be replace TDN. The more ADF in a feed, the lower the DDM value will be. In this experiment, the DDM values for the $a_{0} b_{0} c_{0}$ treatment reached 55.6 and ranged between 53.7 and 57.44 for the fertilized treatments.

The DMI values reached $2.3 \%$ for the $\mathrm{a}_{0} \mathrm{~b}_{0} \mathrm{c}_{0}$ treatment and were higher in all the fertilized treatments. NEL had values between 0.52 and $0.58 \mathrm{Mcal} \cdot \mathrm{kg}^{-1}$ for the $\mathrm{a}_{3} \mathrm{~b}_{3} \mathrm{c}_{2}, \mathrm{a}_{2} \mathrm{~b}_{2} \mathrm{c}_{1}$ and $\mathrm{a}_{2} \mathrm{~b}_{2} \mathrm{c}_{2}$ treatments. TDN represents the sum of digestible crude protein, digestible carbohydrates, and digestible fat. TDN recorded values between 51.9 and 57.3 for the $\mathrm{a}_{2} \mathrm{~b}_{2} \mathrm{c}_{2}$ and $a_{3} b_{3} c_{2}$ treatments.

This research showed that the RFV values ranged between 99.2 and 112.6. The higher NDF in forage will make RFQ a better prediction of quality than RFV. RFQ values ranged between 102.3 for the $a_{0} b_{0} c_{0}$ treatment and 117.6 for the $a_{2} b_{2} c_{1}$ treatment. The RFV values ranged between 99.20 and 112.59 and placed the fodder in the good quality fodder category. 
414

Table 4. Mean cover vascular plant species and mosses (in \%), mean species richness $\left(\mathrm{m}^{-1}\right)$ of the aboveground biomass yield in $2014\left(\mathrm{t} \cdot \mathrm{ha} \mathrm{a}^{-1}\right)$

\begin{tabular}{|c|c|c|c|c|c|c|c|c|}
\hline Species & aoboco & albıcı & albic2 & $\mathrm{a} 2 \mathrm{~b}_{2 \mathrm{Cl}}$ & $\mathrm{a} 2 \mathrm{~b}_{2} \mathrm{C}_{2}$ & $\mathrm{a}_{3} \mathrm{~b}_{3} \mathrm{cl}$ & $\mathrm{a}_{3} \mathrm{~b}_{3} \mathrm{c}_{2}$ & FG \\
\hline Achillea millefolium & 4.1 & 2.3 & 1.8 & 0.8 & 0.7 & 1.1 & 1.6 & $\mathrm{TH}$ \\
\hline Agrostis capillaris & 3.9 & 3.7 & 3.2 & 2.9 & 1.7 & 2.1 & 2.7 & SG \\
\hline Alchemilla vulgaris & 0.1 & 1.2 & 1.6 & 2.1 & 2.6 & 0.7 & 2.6 & SH \\
\hline Anthoxanthum odoratum & 0.9 & 3.8 & 3.4 & 3.2 & 4.6 & 2.2 & 2.4 & SG \\
\hline Anthylis vulneraria & 1.1 & 0.3 & & & & & & $\mathrm{~L}$ \\
\hline Arrhenatherum elatius & 1.9 & 7.7 & 8.2 & 5.6 & 2.7 & 3.1 & 9.3 & TG \\
\hline Brachypodium pinnatum & 2.1 & 1.2 & 0.7 & 1.6 & 2.5 & 2.3 & 2.2 & TG, R \\
\hline Briza media & 4.1 & 3.8 & 2.3 & 0.1 & 1.8 & 3.9 & 2.1 & SG \\
\hline Carex tomentosa & & & & 0.7 & 0.4 & & & SH \\
\hline Leucanthemum vulgare & 0.9 & 0.7 & 0.5 & 0.6 & 0.4 & 0.7 & 0.6 & $\mathrm{TH}$ \\
\hline Colchicum autumnale & 0.1 & & 0.7 & 0.5 & 0.9 & 1.1 & & SH \\
\hline Cynosurus cristatus & 1.2 & 1.3 & 0.6 & 1.8 & 1.6 & 1.7 & 0.6 & SG \\
\hline Dactylis glomerata & 0.8 & 1.2 & 7.1 & 2.7 & 2.2 & 1.5 & 4.5 & TG \\
\hline Festuca pratensis & 0.1 & 0.4 & & & 1.2 & 1.6 & 1.8 & TG \\
\hline Festuca rubra & 4.0 & 4.5 & 7.1 & 10.3 & 10.8 & 7.8 & 6.7 & TG, R \\
\hline Filipendula vulgaris & 3.3 & 2.3 & 3.2 & 2.8 & 3.3 & 2.6 & 2.1 & $\mathrm{TH}$ \\
\hline Galium verum & 1.7 & 1.4 & 1.1 & 2.2 & 1.4 & 1.9 & 1.1 & SH \\
\hline Genista tinctoria & & 1.1 & & 1.4 & 0.5 & 1.1 & 1.3 & $\mathrm{~L}$ \\
\hline Hypericum maculatum & & 1.2 & 0.9 & 1.8 & 0.7 & 1.4 & 1.1 & SH \\
\hline Knautia arvensis & & & & 0.2 & 0.4 & & & TH \\
\hline Lathyrus pratensis & & & & & & & 0.4 & $\mathrm{~L}$ \\
\hline Lotus corniculatus & 2.4 & 5.7 & 5.6 & 5.1 & 3.4 & 2.5 & 2.2 & $\mathrm{~L}$ \\
\hline Medicago lupulina & & & 0.1 & & & & & $\mathrm{~L}$ \\
\hline Nardusstricta & 45.6 & 16.3 & 14.2 & 16.7 & 17.8 & 16.6 & 15.5 & SG, R \\
\hline Plantago lanceolata & 3.5 & 1.2 & 3.3 & 1.1 & 3.3 & 1.2 & 2.1 & SH \\
\hline Plantago media & 1.5 & & & 0.1 & & 1.3 & & SH \\
\hline Poapratensis & & & 1.2 & & & & & TG, R \\
\hline Potentilla erecta & 1.6 & 0.1 & 1.1 & 0.7 & 0.1 & 0.8 & 1.1 & SH \\
\hline Prunella vulgaris & 0.1 & 1.2 & 0.7 & 0.6 & & 1.1 & & $\mathrm{SH}$ \\
\hline $\begin{array}{c}\text { Ranunculus polyanthemos subsp. } \\
\text { polyanthemoides }\end{array}$ & 0.3 & 1.3 & & 1.4 & 0.5 & 1.2 & 0.6 & $\mathrm{TH}$ \\
\hline Taraxacum officinale & & 1.1 & 3.1 & 2.2 & 1.8 & 2.9 & 3.3 & $\mathrm{SH}$ \\
\hline Thymus pulegioides & 1.2 & 1.8 & 1.2 & 0.8 & 1.1 & 0.7 & & $\mathrm{TH}$ \\
\hline Trifolium montanum & & 1.3 & & 0.6 & & 2.4 & & $\mathrm{~L}$ \\
\hline Trifolium pratense & 2.1 & 12.2 & 10.1 & 12.3 & 15.6 & 12.2 & 10.2 & $\mathrm{~L}$ \\
\hline Trifolium repens & 1.8 & 11.6 & 7.4 & 8.9 & 7.7 & 11.1 & 7.7 & $\mathrm{~L}$ \\
\hline Trisetum flavescens & & 1.7 & 6.6 & 3.3 & & & 8.8 & TG \\
\hline Mean species richness (per m) & 20 & 28 & 27 & 30 & 27 & 29 & 26 & \\
\hline Cover of mosses & 1 & 1.1 & 2.2 & 1.8 & 3.3 & 2.9 & 2.3 & \\
\hline Abovegrounds biomass yield in 2011 & 3.3 & 49 & 5.0 & 4.5 & 4.8 & 4.7 & 4.9 & \\
\hline
\end{tabular}

FG - functional group (L - legumes, R - rhizomatous grasses, TG - tall graminoids, SG - short graminoids, SH short herbs, TH - tall herbs).

Table 5. Diversity parameters

\begin{tabular}{ccccc}
\hline Treatments & Species richness (no) & Shannon index & Shannon evenness & Simpson index (D) \\
\hline $\mathrm{a}_{0} \mathrm{~b}_{0} \mathrm{c}_{0}$ & 20 & 2.202 & 0.745 & 0.225 \\
$\mathrm{a}_{1} \mathrm{~b}_{1} \mathrm{C}_{1}$ & $28^{*}$ & $2.837^{*}$ & $0.852^{*}$ & $0.083^{*}$ \\
$\mathrm{a}_{1} \mathrm{~b}_{1} \mathrm{C}_{2}$ & $27^{*}$ & $2.950^{*}$ & $0.895^{*}$ & $0.066^{*}$ \\
$\mathrm{a}_{2} \mathrm{~b}_{21}$ & $30^{*}$ & $2.934^{*}$ & $0.863^{*}$ & $0.077^{*}$ \\
$\mathrm{a}_{2} \mathrm{~b}_{2} \mathrm{c}_{2}$ & $27^{*}$ & $2.805^{*}$ & $0.851^{*}$ & $0.089^{*}$ \\
$\mathrm{a}_{3} \mathrm{~b}_{3} \mathrm{C}_{1}$ & $29^{*}$ & $2.964^{*}$ & $0.880^{*}$ & $0.073^{*}$ \\
$\mathrm{a}_{3} \mathrm{~b}_{3} \mathrm{C}_{2}$ & $26^{*}$ & $2.916^{*}$ & $0.895^{*}$ & $0.070^{*}$ \\
$L S D 5 \%$ & 5 & 0.515 & 0.101 & 0.082 \\
\hline
\end{tabular}

Indices of biodiversity: species richness (no), Shannon index, Shannon evenness and Simpson index (D) was calculated for the last years of the experimentation; The cover of all vascular plant species was visually estimated in each plot based on the Braun-Blanquet methodology. To eliminate edge effects, relevés were taken in the center of each $4 \mathrm{~m} \times 5 \mathrm{~m}$ plot in an area of $2 \mathrm{~m} \times 3 \mathrm{~m}$ in mid-June 2013. The total number of vascular plant species was counted directly in the field. 
Table 6. Chemical composition and nutritional value of the fodder harvested in $2014\left(\mathrm{~g} \cdot \mathrm{kg}^{-1} \mathrm{DM}\right)$

\begin{tabular}{|c|c|c|c|c|c|c|c|c|c|c|c|}
\hline Treatments & $\begin{array}{c}\text { Total } \\
\text { nitrogen }\end{array}$ & $\mathrm{CA}$ & $\mathrm{ADF}$ & NDF & $\begin{array}{c}\text { DDM } \\
(\%)\end{array}$ & $\begin{array}{c}\text { DMI } \\
(\% \text { of BW) }\end{array}$ & NFC & 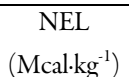 & TDN & RFV & RFQ \\
\hline $\mathrm{a}_{0} \mathrm{~b}_{0} \mathrm{c}_{0}$ & 13.7 & 92.9 & 427.6 & 521.3 & 55.6 & 2.30 & 27.5 & 0.55 & 54.7 & 99.2 & 102.3 \\
\hline albicı & 14.5 & $99.3^{*}$ & 430.7 & $469.3^{\circ}$ & 55.4 & $2.56^{*}$ & $31.5^{*}$ & 0.55 & 54.4 & $109.7^{*}$ & $113.2^{*}$ \\
\hline$a_{1} b_{1} c_{2}$ & 14.1 & 91.6 & 416.8 & $489.0^{\circ}$ & 56.4 & 2.45 & $30.2^{*}$ & 0.57 & 55.9 & 107.2 & $111.4^{*}$ \\
\hline $\mathrm{a}_{2} \mathrm{~b}_{2} \mathrm{c}_{1}$ & 14.7 & $88.7^{\circ}$ & $407.7^{\circ}$ & $472.1^{\circ}$ & $57.1^{*}$ & $2.54^{*}$ & $30.9^{*}$ & $0.58^{*}$ & $56.9^{*}$ & $112.6^{*}$ & $117.6^{*}$ \\
\hline $\mathrm{a}_{2} \mathrm{~b}_{2} \mathrm{c}_{2}$ & 14.8 & $82.6^{\circ}$ & $404.1^{\circ}$ & 504.7 & $57.4^{*}$ & 2.38 & 29.4 & $0.58^{*}$ & $57.3^{*}$ & $105.8^{*}$ & $110.9^{*}$ \\
\hline $\mathrm{a}_{3} \mathrm{~b}_{3} \mathrm{Cl}_{1}$ & $15.8^{*}$ & 91.6 & 422.3 & $484.9^{\circ}$ & 56.0 & 2.47 & 29.7 & 0.56 & 55.3 & $107.4^{*}$ & $111.0^{*}$ \\
\hline$a_{3} b_{3} c_{2}$ & $16.1^{*}$ & $97.6^{*}$ & $452.5^{*}$ & $479.2^{\circ}$ & $53.7^{\circ}$ & 2.50 & 30.0 & 0.52 & $51.9^{\circ}$ & 104.2 & 105.6 \\
\hline LSD 5\% & 1.5 & 2.3 & 15.6 & 24.8 & 1.1 & 0.22 & 2.6 & 0.03 & 1.8 & 5.4 & 4.7 \\
\hline
\end{tabular}

CA - crude ash; ADF - acid detergent fiber; NDF - neutral detergent fiber; DDM - digestible dry matter; DMI - dry matter intake; RFV - relative feed value; RFQ relative feed quality; NFC - no fibrous carbohydrates; NEL - net energy lactation; TDN -total digestible nutrients.

\section{Discussion}

As the mean annual herbage yield was only $2.2 \mathrm{t} \mathrm{ha}^{-1}$ in the control, the experimental grassland was classified as low productive. In Central Europe, the annual herbage yield of highly productive grasslands without any fertilizer input is over $4 \mathrm{t} \mathrm{ha}^{-1}$ (Hrevušová et al., 2009).

The results of this study indicated that fertilization treatments were able to maintain a high diversity of species. Production was influenced by fertilizer application rate and the combination fertilizers applied. Festuco rubrae Agrostietum capillaris grasslands respond very well to different fertilization treatments in terms of forage Dry Matter (DM) production. All fertilized treatments recorded higher yields than any of the unfertilized treatments, because the soil on which many of these grasslands grow is nutrient poor and fertilizer input always leads to significant yield increases.

The amount of available $\mathrm{N}$ in applied slurry was not high enough to simultaneously increase yield and $\mathrm{N}$ concentration in the herbage and thus, the proportion of $\mathrm{N}$ poor stems in the biomass occurred (Liebisch et al., 2013). Herbage $\mathrm{N}$ deficiency corroborated herbage $\mathrm{N}$ concentration values lower than $20 \mathrm{~g} \mathrm{~kg}^{-1}$ (Bailey et al., 1997).

In 2014, there was a positive correlation between the number of species and rate of production. Thus, the control output was $290 \mathrm{~g} \cdot \mathrm{sqm}^{-1}$ and the number of recorded species was 20. The fertilized treatments offered total yields that ranged between 320 and 430 g.sqm ${ }^{-1}$ and the number of species varied between 26 and 30 . This increase in the number of species was due to the fertilizer applications changing the soil fertility state. The implicit change in terms of soil fertility also allowed other species, mesotrophic or eutrophic, to thrive under the improved conditions. Furthermore, the applied manure improved the number of species present, especially in the "plants from other botanical families” group (Păcurar et al., 2012).

A possible explanation for the lack of negative effect of slurry application on species richness is the shallow and permeable soil that limited water and nutrient availability thus preventing predominance of tall grasses under high slurry application rates (Araya et al., 2013).

The small application rates of manure, applied at varying intervals, together with small application rates of fertilizer, clearly contributed to improving the number of species present in the vegetation cover. There are some changes in plant species and in functional plant groups under the different fertilization treatments (Honsová et al., 2007).

Botanical composition was very poor and forage species of little botanical value accounted for most of its structure. The increase in the number of species was probably due to either the improved nutrition of the studied terrains, or to the contribution made by the application of manure.

The nitrogen nutrient status, indicated by the NNI values, showed that the soil in this area lacked nutrients and therefore it is recommended that higher application rates of nitrogen are made.

Numerous studies have revealed positive relationships between biodiversity and fertilization (Hejcman et al., 2010; Reiss et al., 2011). Grassland species richness has been linked with the type of fertilizers applied (Cao et al., 2011).

In Apuseni Mountain from Romania, the mineral and organic fertilizers administration on the Festuca rubra Agrostis capillaris grassland type produced important changes within the sward depending on the applied treatments (Păcurar et al., 2012). In this study, Păcurar et al. (2012), administrating $\mathrm{N}_{50} \mathrm{P}_{25} \mathrm{~K}_{25}$ and $10 \mathrm{t} \cdot \mathrm{ha}^{-1}$ manure generated the installation of Festuca rubra and Agrostis capillaris grassland type. The treatments with $\mathrm{N}_{100} \mathrm{P}_{50} \mathrm{~K}_{50}$ and $\mathrm{N}_{150} \mathrm{P}_{75} \mathrm{~K}_{75}$ caused the occurrence of Agrostis capillaris and Trisetum flavescens grassland type.

NFC represents high digestibility carbohydrates that are not recovered in the NDF fraction. Net energy for lactation (NEL) is the term used for assessing the energy requirements and feed values for lactating cows.

DMI is an estimate of the amount of feed an animal will consume in percent of body weight and is calculated using NDF value. Feeding studies have shown that as percentage NDF increases in the forage grass, livestock consumption declines. Neutral detergent fiber has been shown to be negatively correlated with dry matter intake.

Using a low input-based management system can be a solution that will lead to higher yields and contribute to biodiversity conservation and the good quality of the forage. The small quantities of organic and mineral nutrients (10 t.ha ${ }^{-1}$ manure and $30 \mathrm{~kg} \cdot \mathrm{ha}^{-1}$ nitrogen) can lead to larger yields while at the same time, improving biodiversity conservation and the quality of forage. 
416

\section{Conclusions}

Production was influenced by climatic conditions, fertilizer application rate and the combination fertilizers applied. Festuco rubrae - Agrostietum capillaris grasslands respond very well to different fertilization treatments in terms of forage Dry Matter (DM) production. All fertilized treatments recorded higher yields than any of the unfertilized treatments, because the soil on which many of these grasslands grow is nutrient poor and fertilizer input always leads to significant yield increases. The small application rates of manure, applied at varying intervals, together with small application rates of fertilizer, clearly contributed to improving the number of species present in the vegetation cover. Using a low input-based on small rate of fertilizers can be a solution that will lead to higher yields and contribute to biodiversity conservation and the good quality of the forage. The forage quality was very well to the small fertilizer application rate and the combination fertilizers applied. The use of a fertilizer management regime based on small quantities of organic and mineral nutrients can lead to larger yields while at the same time, improving biodiversity conservation and the quality of forage.

\section{References}

Andueza D, Cruz P, Farruggia A, Baumont R, Picard F, Michalet-Doreau B (2010). Nutritive value of two meadows and relationships with some vegetation traits. Grass and Forage Science 65:325-334.

Araya YN, Gowing DJ, Dise N (2013). Does soil nitrogen availability mediate the response of grassland composition to water regime? Journal Vegetation Science 24:506-517.

AssafTA, Beyschlag W, Isselstein J (2011). The relationship between plant diversity and productivity in natural and in managed grasslands. Applied EcologyEnvironmental Research 9:157-166.

Bailey JS, Cushnahan A, Beattie JAM (1997). The diagnosis and recommendation integrated system (DRIS) for diagnosing the nutrient status of grassland swards: II. Model calibration and validation. Plant and Soil 197:137-147.

Bruinenberg MH, Valk H, Korevaar H, Struik PC (2002). Factors affecting digestibility of temperate forages from seminatural grasslands: a review. Grass and Forage Science 57:292-301.

Cao J, Holden NM, Lü XT, Du G (2011). The effect of grazing management on plant species richness on the Qinghai-Tibetan Plateau. Grass and Forage Science 66:333-336.

Chapin FS, Zavaleta ES, Eviner VT, Naylor RL, Vitousek PM, Reynolds HL, ... Diaz S (2000). Consequences of changing biodiversity. Nature 405:234242.

Chytrý M, Hejcman M, Hennekens S, Schellberg J (2009). Changes in vegetation types and Ellenberg indicator values after 65 years of fertilizer application in the Rengen Grassland Experiment, Germany. Applied Vegetation Science 12:167-176.

Coleman SW, Moore JE (2001). Feed quality and animal performance. FieldCrop Research 84:17-29.

Cristea V, Gafta D, Pedrotti F (2004). Fitosociologie. Editura Presa Universitară Clujeană(in Romanian).

Dale LM, PiernaJF, Vermeulen P, Lecler B, Bogdan AD, Păcurar F, Rotar I,
Thewis A, Baeten B (2012). Research on crude protein and digestibility of Arnica montana L. using conventional NIR spectrometry and hyperspectral imaging NIR Journal of Food, Agriculture and Environment 10:391-396.

Duru M, Cruz P, Theau JP (2010). A simplified method for characterising agronomic services provided by species-rich grasslands. Crop Pasture Science 61:420-433.

Hejcman M, Schellberg J, Pavlù V (2010). Long-term effects of cutting frequency and liming on soil chemical properties, biomass production and plant species composition of Lolio-Cynosuretum grassland after the cessation of fertilizer application. Applied Vegetation Science 13:257269.

Honsová D, Hejcman M, Klaudisová M, Pavlů V, Kocourková D, Hak J (2007). Species composition of an alluvial meadow after 40 years of applying nitrogen, phospohorus and potassium fertilizer. Preslia 79:245258.

Hopkins A, Gilbey J, Dibb C, Bowling PJ, Murray PJ (1990). Response of permanent and reseeded grassland to fertilizer nitrogen. 1. Herbage production and herbage quality. Grass and Forage Science 45:43-55.

Hopkins A, Pywell R, Peel S, Johnson R, Bowling P (1999). Enhancement of botanical diversity of permanent grassland and impact on hay production in Environmentally Sensitive Areas in the UK. Grass and Forage Science 54:163-173.

Hrevušová Z, Hejcman M, Pavlu VV, Hakl J, Klaudisová M, Mrkvicka J (2009). Long-term dynamics of biomass production, soil chemical properties and plant species composition of alluvial grassland after the cessation of fertilizer application in the Czech Republic. Agriculture, Ecosystems \& Environment 130:123-130.

Kesting S, Wrage N, Isselstein J (2009). Herbage mass and nutritive value of herbage of extensively managed temperate grasslands along a gradient of shrubencroachment. Grass and Forage Science 64:246-254.

Lemaire G, Gastal F, Salette J (1989). Analysis of the effect of N nutrition on dry matter yield of a sward by reference to potential yield and optimum $\mathrm{N}$ content. Proceedings of of the 16th International Grassland Congress, Nice, Francepp 179-180.

Liebisch F, Bünemann EK, Huguenin-Elie O, Jeangros B, Frossard E, Oberson A (2013). Plant phosphorus nutrition indicators evaluated in agricultural grasslands managed at different intensities. European Journal of Agronomy 44:67-77.

Louault F, Pillar VD, Aufrère J, Garnier E, Soussana JF (2004). Plant traits functional types in response to reduced disturbance in a semi-natural grassland. Journal of Vegetation Science 16:151-160.

Oates LG, Undersander DJ, Gratton C, Bell MM, Jackson RD (2011). Management-intensive rotational grazing enhances forage production and quality of subhumid cool-season pastures. Crop Science 51:892901.

Pasho E, Papanastasis VP, Pelz D, Lakos T (2011). Inventory and evaluation of grasslands in Albania. Grass and Forage Science 66:123-137.

Păcurar F, Rotar I, Bogdan AD, Vidican R, Dale LM (2012). The influence of mineral and organic long-term fertilization upon the floristic composition of Festuca rubra L. - Agrostis capillaris L. grassland in Apuseni mountains, Romania. Journal of Food, Agriculture and Environmental 10:866-879.

Reiss J, Bailey RA, Perkins DM, Pluchinotta A, Guy W (2011). Testing 
effects of consumer richness, evenness and body size on ecosystem functioning Journal of Animal Ecology 80:1145-1154.

Samuil C, Vintu V, Sîrbu C, Popovici CI (2012a). Influence of fertilization on the vegetation and production of Festuca valesiaca L. grassland. Fourrages 210:151-157.

Samuil C, Vintu V, Sîrbu C, Surmei GB (2012b). Behaviour of fodder mixtures with alfalfa in North-Eastern Romania. Romanian Agriculture Research 29:227-235.

Sara A, Odagiu A (2005). Controlul calitatii nutreturilor. Editura AcademicPres Cluj-Napoca (in Romanian).

Sîrbu C, Oprea A, Samuil C, Tănase C (2012). Neophyte invasion in Moldavia (eastern Romania) in different habitat types. Folia Geobotanica 46:215-229.
Vîntu V, Samuil C, Rotar I, Moisuc A, Razec I (2011a). Influence of the management on the phytocoenotic biodiversity of some Romanian representative grassland types. Notulae Botanicae Horti Agrobotanici Cluj-Napoca 39:119-125.

Vîntu V, Samuil C, Sîrbu C, Popovici CI, Stavarache M (2011b). Sustainable Management of Nardus stricta L. Grasslands in Romania’s Carpathians. Notulae Botanicae Horti Agrobotanici Cluj-Napoca 39:142-145.

Yu YW, Fraser MD, Evans JG (2011). Long-term effects on sward composition and animal performance of reducing fertilizer inputs to upland permanent pasture. Grass and Forage Science 66:138-151. 